\title{
Review
}

\section{Secrets and democracy: From arcana imperii to Wikileaks}

\author{
Lawrence Quill \\ Palgrave Macmillan, Basingstoke, 2014, 182pp., ISBN: 978-0-230-36777-7
}

Contemporary Political Theory (2018) 17, S82-S85. https://doi.org/10.1057/s41296017-0119-x; published online 26 May 2017

In 2015, the British Intelligence and Security Committee - the parliamentary body responsible for overseeing the intelligence services - released a report endorsing the principle of bulk data collection (ISC, 2015). In other words, the committee sanctioned the interception and collection of vast quantities of communications data en masse. Despite pleas from privacy campaigners that such bulk interception violated a fundamental human right to privacy, the committee concluded that the promise of possibly preventing future terrorist attacks was more important. Two years later, the committee chastised the government for refusing to reveal information pertaining to the use of intelligence related to the targeted killing of a British national, Reyaad Khan (ISC, 2017). Proper scrutiny of the executive could not be achieved, the committee protested, without full access to the archive. These are just two instances of the tension between secrecy and revelation that besets liberal democracy. Personal secrecy (or privacy) is integral to the liberal character of the state, and yet the sacrifice of such secrecy may be required to protect the state. Meanwhile, both political secrecy, and the revelation of such secrets, can simultaneously preserve and endanger good governance. How are we to interpret these dilemmas of dismantling privacy or contesting political secrecy? In Secrets and Democracy, Lawrence Quill argues that of all the political binaries that permeate Western democratic life - from security/liberty to public/private - it is secrecy/revelation that is in the direst need of political theorizing and historicization within political thought. By undertaking that project, Quill promises a new appreciation of power within modern western democracy.

Quill's work follows others, such as Horn (2011), who have traced the emergence of a liberal attitude towards secrecy. Since the dawn of raison d'État, secrecy has supported the 'epistemic project of modern statehood' in which state bureaucracies collect knowledge about populations and territories (p. 10). In response, liberal political thinkers such as Mill and Bentham have pursued greater transparency and openness as a means of protecting the individual from the dangers posed by excessive secrecy. Today, this contestation has given rise to a political

(c) 2017 Macmillan Publishers Ltd. 1470-8914 Contemporary Political Theory Vol. 17, S2, S82-S85 
culture of 'balancing' the liberties of freedom, privacy, and openness against the necessities of security. Like many others, Quill rightly dismisses the balance metaphor as misleading (p. 58). There is no reason to think that the sacrifice of liberties would increase security, and there is every reason to think that diminishing liberty might diminish the security of citizen against the excesses of state power. Acknowledging that democracy requires a minimum degree of liberty at all times, Quill suggests that in moments of crisis, it is the value of courage, rather than security, that ought to be preserved (p. 64).

So far, Quill's line of enquiry closely follows existing scholarly interventions. The innovation of the book is found in Quill's further demonstration that, in two ways, this liberal project of publicity and privacy is no longer fit for purpose in the 'network age' of the twenty-first century (p. 94). The first concerns the idea, central to liberal thought, that the individual is sovereign. Today, the modern state remains concerned with the collection, analysis, and storage of information. Now, however, new technologies facilitate these efforts in an ever more intensive and intrusive fashion. Quill notes the traditional liberal defence of privacy, citing Berlin's and Mill's claims that privacy protects a minimum degree of personal freedom, which in turn facilitates the development of one's faculties, which in turn supports liberal pluralism and private economic interests (p. 100). In the participatory panopticon of modern life, however, we are incentivised to give privacy away. On the one hand, individuals treat their private information as a commodity that can be traded for a perceived benefit - from fitness tracking to supermarket discounts. In such circumstances, where participation in the economic system depends on the sacrifice of personal secrecy, Quill warns that privacy may become a privilege that only the 'wealthy or well placed' can afford (p. 123). On the other hand, the modern state appeals to the citizenry to accept surveillance (and to surveil each other) on the promise that, eventually, technological sophistication will eliminate the risks and insecurities of the globalized world (p. 118). We now live, Quill argues, in a 'networked society' that in turn requires a 'networked self' (p. 113). The liberal defence of privacy is outdated. The concepts of liberal theory 'simply don't have the wherewithal to cope with the challenges posed by the technology that has led to social networks or drones' (p. 123). This may be the end of personal secrecy as we know it. The consequences of this post-privacy society, however, remain to be seen.

Quill's second intervention is to consider the role of revelation, particularly when committed as an unauthorized act by organizations such as Wikileaks. Since 2006, Wikileaks has dumped vast quantities of secrets on the internet, ranging from military activity logs to diplomatic cables, revealing military errors, espionage, extra-legal killings and mistreatment of detainees. On the one hand, these actions could be interpreted as part of the liberal project of publicity, facilitating the public's right to know. In Quill's words, 'a corrective against government's excessive secrecy' necessary for an enlightened citizenry (p. 124). On the other

(c) 2017 Macmillan Publishers Ltd. 1470-8914 Contemporary Political Theory Vol. 17, S2, S82-S85 S83 
hand, however, Quill argues that the leaks, "rather than undermining an "unjust" system, may, paradoxically, have strengthened it' (p. 126). Rather than usher in a new era of counter-culture or open government, the United States' response to the leaks has been greater safeguards against unauthorized disclosure and a public largely embarrassed rather than outraged by the revelations.

Quill suggests two reasons for this paradox of Wikileaks. The first is 'conspiracy culture' (p. 135). Building on the work of Dean (2002), Quill suggests that in our contemporary networked society, there is a 'hyper-informed citizenry' that is simultaneously overwhelmed by information and unable to trust any of it (p. 140). This stands in stark contrast to the beliefs of early liberals that more publicity would provide the citizenry with greater control over the state. Suspicion has become the norm of democratic politics, but no amount of exposure will resolve that distrust. The readers of Wikileaks' revelations experienced a sense of powerlessness, reminding them of their ignorance of the mysteries of the state. At the same time, Quill claims, some of the revelations were so disquieting that it was difficult to know whether to believe the denials and excuses of the United States government or the accusations of conspiracy from Julian Assange. 'Precisely because it was so hard to determine what to believe about the revelations', Quill argues, 'it was easier, overall, to ignore them' (p. 142).

The public, however, are not mere victims. Quill's second claim is that liberal democratic publics are complicit in a project of mass hypocrisy. The facts revealed by Wikileaks - from killing to espionage - were 'public secrets' (Taussig, 1999). That is, they were something that most people knew (or at least suspected) but chose not to discuss. What the revelations demonstrated, Quill claims, is 'that most Western citizens were already aware of their government's wrongdoing and, while most were comfortable with that, they were less comfortable being reminded of it' (p. 144). Wikileaks did not so much expose state crime as it exposed the limits of liberal publicity. Quill goes so far as to argue that this sort of hypocrisy is a necessary part of the functioning of modern liberal democracies: a society that prides itself on openness, transparency, and freedom of speech, but where in reality there are some things that are taboo to discuss.

Quill's work leaves us with many stimulating if troubling questions. What are the effects of a post-privacy society? How might a right to privacy be defended when it seems that attempts to preserve liberal democratic life increasingly depend on the suspension of personal privacy? What is the role of truth-telling in a liberal democracy? This last question is perhaps the most important. Quill's claim is that liberal democracies have slid into a 'culture of bullshit' where no one believes anything anyone says anymore (p. 146). This is, of course, a prescient claim given the rise of 'post-truth' politics. Quill is writing about epistemological claims that are open to dispute because the networked society is simultaneously so democratised and disenfranchised that factual claims are easily contested or ignored. Perhaps, though, this still leaves some hope for the parrhesiast - the 
person who speaks a disruptive truth to the powerful, placing the speaker at great risk, where that truth cannot be judged by epistemological standards (Foucault, 2011). Parrhesia is not about disclosing what has been done or decided. Rather it is concerned with an objection to an otherwise accepted way of thinking. If, as Quill claims, liberal publics are complicit in ignoring state crime, perhaps a progressive politics can be found in the courageous acts of those who criticize our subjectivity. Doing nothing, Quill warns, will leave us sliding towards a mere 'simulacra [sic] of democracy' where human rights and freedoms exist in name only (p. 152).

\section{References}

Dean, J. (2002) Publicity's Secret. New York: Cornell University Press.

Foucault, M. (2011) The Government of Self and Others: Lectures at the College de France, 1982-1983. Basingstoke: Palgrave Macmillan.

Horn, E. (2011) Logics of political secrecy. Theory, Culture \& Society, 28(7), 103-122.

ISC. (2015) Privacy and Security: A Modern and Transparent Legal Framework. London: The Stationery Office.

ISC. (2017) UK Lethal Drone Strikes in Syria. London: The Stationery Office.

Taussig, M. (1999) Defacement: Public Secrecy and the Labor of the Negative. Stanford: Stanford University Press.

Owen D. Thomas

University of Exeter, Exeter EX4 4QJ, UK o.d.thomas@exeter.ac.uk 